\title{
New late-season navel orange varieties evaluated for quality characteristics
}

\author{
by Tracy L. Kahn, Ottillia J. Bier \\ and Robert J. Beaver
}

\begin{abstract}
New early- and late-maturing navel orange varieties have expanded the navel orange season for California's domestic and export fresh-fruit market. For 5 years, we evaluated the fruit-quality characteristics of purported late-season varieties imported from Australia to determine whether they have any advantages over Lane Late, the first late-season navel orange imported from Australia and grown in California. Of the six varieties evaluated, Autumn Gold, Barnfield,
\end{abstract} Chislet, Powell and Lane Late had late-maturing characteristics, but none of these varieties stood out as having the latest maturing fruit for all traits associated with maturity at all nine locations studied. For certain locations, sample dates and years, there were significant differences among the varieties for quality traits associated with maturity, such as solids-to-acid ratio, percentage acidity and puncture resistance, but these differences varied depending upon location.

\footnotetext{
For most people, a navel orange is a navel orange. Most consumers are not aware that throughout the year, the navel orange bin in the grocery store may contain as many as 22 commercial varieties. The increased number of varieties that reach legal maturity earlier or later than the Washington navel variety, which has been the standard since the late 19th century in California, has had a dramatic effect on the fresh orange market. Over the past few years, the return to growers for Valencia* oranges has dropped in California, resulting in a reduction in Valencia acreage. This is due in part to the importation of late-season navel
}



Researchers with the Citrus Variety Collection at UC Riverside (shown) evaluated the quality characteristics of late-maturing navel oranges grown here and at collaborating orchards around California.

oranges from Australia and to recent new plantings of late-season navel varieties in California, which are more highly colored and easier to peel than Valencia oranges (NASS 2006). The introduction of new late-season navel orange varieties has extended the season for navel oranges in California's domestic and export fresh fruit market.

The majority of new navel varieties originate from a mutation or genetic change in a vegetative bud, commonly called a "bud sport" or "limb sport." The selection of a bud sport with altered fruit or tree characteristics, such as a change in the timing of fruit maturity, is the most common method for developing new orange varieties. This is a different process from conventional citrus breeding, which involves crossing selected parents and then selecting potentially promising hybrid seeds that result from recombination of the genes during sexual reproduction.

\section{Selection of bud sports}

For types of citrus that do not normally produce seeds, such as navel and Satsuma mandarin oranges, the selection of potentially desirable bud sports is the only viable means of developing new varieties. The selection of bud mutations from the Washington navel orange has resulted in most of our current varieties, such as Thomson, Carter, Gillette, Newhall, Atwood, Bonanza, Fisher, Beck and Cara Cara, a navel orange with pink flesh like that of a red grapefruit.

In California, the Citrus Clonal Protection Program (CCPP) - a cooperative program between the UC Riverside Department of Plant Pathology and California citrus growers, represented by the California Citrus Research Board (CRB), California Citrus Nursery Board and California Department of Food and Agriculture (CDFA) - provides a safe mechanism for the introduction of citrus varieties into the state from any citrus-growing area of the world (www.ccpp.ucr.edu). Approximately $90 \%$ of the new varieties introduced by the ССРP originated as bud sports of other varieties. One such variety is Lane Late, a late-maturing Australian bud sport of Washington navel that was introduced into California in 1973. Comparison of Lane Late fruit with that of the Washington, Newhall, Fisher and Atwood varieties found that Lane Late holds on the tree much better than the midseason varieties 
TABLE 1: Rootstocks and interstocks for varieties grown at nine cooperator locations

Parent and Atwood and early-maturing strains such as Fisher and Newhall (Nauer et al. 1990).

Lane Late is now an important commercial navel-orange variety in California, Australia and other citrus-production regions of the world. The success of the late-season navel orange market in Australia, which paid higher returns for Lane Late, coupled with plant-breeders-rights legislation in Australia permitting the patenting of new navel varieties, encouraged Australian growers to search for new late-maturing navel orange varieties in the early 1980s.

A number of new late-maturing navel orange selections were identified by Australian growers and evaluated by Gallasch $(1996,1997)$. Comparisons of these late-hanging selections in Australia demonstrated small but significant fruit-quality differences in some years and not others. For example, midto late-season varieties that had the best internal fruit quality based on total soluble solids were Wiffen, Powell, Summer Gold, Hutton, Christensen and Autumn Gold. Late in the Australian season (December), Wiffen, Lane Late, Wilson, Powell and Hutton had the highest acid contents, which is associated with good flavor (Gallasch 1996, 1999).

In the late 1980s and early 1990s, five (Autumn Gold, Barnfield, Chislett, Powell and Summer Gold) of the 12 varieties evaluated in Australia were sent to the CCPP for quarantine and then released for propagation in California in 1991 and 1992. The California Citrus Nursery Society (CCNS) agreed to facilitate the testing of these late navel varieties, which are currently licensed in California. Most of the nurseries that participated in testing these selections top-worked (with buds of the new variety grafted onto the former scion, now called "interstock") two existing trees with Autumn Gold, Chislett, Powell, Summer Gold and Lane Late budwood. In 1996, in cooperation with the CCNS and five cooperating citrus nurseries, our laboratory began the first extensive fruit-quality evaluations of these varieties in California. In 1997, two additional nurseries agreed to collaborate at multiple locations.

The top-worked trees at collaborating nurseries differed in rootstocks and interstocks (table 1). These differences

\begin{tabular}{lccc}
\hline \hline Cooperator location & \multicolumn{1}{c}{ Varieties } & Interstock & Rootstock \\
\hline Madera* & All except Barnfield & Frost nucellar navel & Trifoliate \\
Orange Cove & All except Barnfield & Valencia & Troyer \\
Woodlake & All except Barnfield & Washington navel & Trifoliate \\
Lindsay & Barnfield, Lane Late & None & Carrizo \\
Ducor & All except Barnfield & Atwood & Carrizo \\
Delano & Barnfield only & None & Carrizo \\
Arvin & All except Barnfield & Brazilian Sour & Troyer \\
Ojai & All except Barnfield & None & Carrizo \\
Fillmore & All except Barnfield & None & Carrizo \\
\hline * In Madera, Lane Late trees were on Carrizo rootstock with no interstock. & &
\end{tabular}
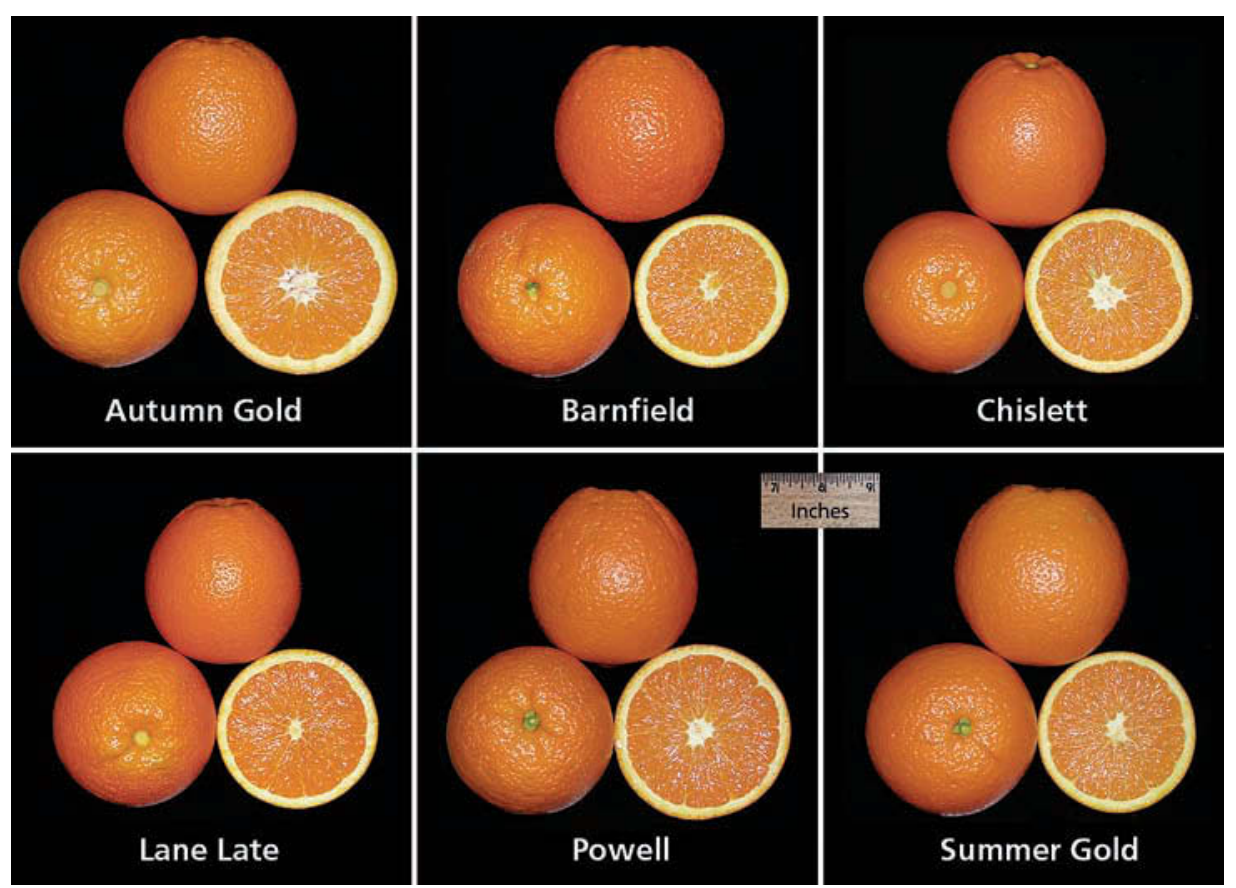

Powell

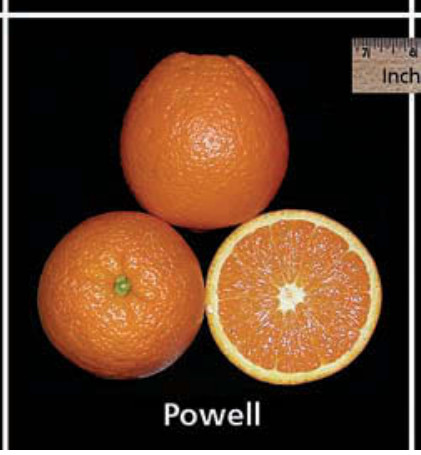

Summer Gold

The late-maturing navels were developed from bud sports - genetic changes in vegetative buds - of Australian varieties. Lane Late has been an important late-maturing commercial variety in California since the 1970s, but others are being planted.

are known to affect tree performance and fruit-quality factors such as soluble solids, acid concentration and their ratio; however, when we began this study, these were the only trees available for evaluation in California (Castle 1995). To date, this is the largest and longest study in the United States evaluating these late-season navel orange varieties from multiple locations.

\section{Evaluating fruit quality}

The eight cooperating nurseries covered a 220-mile span from north to south in the San Joaquin Valley and Central Coast: Madera, Orange Cove, Woodlake, Ducor, Delano, Lindsay, Arvin, Ojai and Fillmore (table 1). All sites except two (Lindsay and Delano) contained the following late navel selections: Autumn Gold, Chislett, Powell, Summer Gold and Lane Late. One of the remaining sites was planted exclusively to Barnfield (Delano), and the other was planted to Barnfield and Lane Late (Lindsay). Two trees of each variety per site were available for sampling, except for the two sites planted to Barnfield. At that site, six trees were sampled and at the remaining site, four Barnfield and two Lane Late trees were sampled. The cultural practices at each grower-cooperator site were essentially the same.

Trees from each site were sampled three times in 1996 starting January 1996, and four times per season at the same time each year from 1997 to 2001, when fruit was available: (1) late February/early March, (2) late March/early April, (3) third week of May and (4) late June/early July. After the first year of the study, the January sample date was eliminated and the late February and late June/early July 


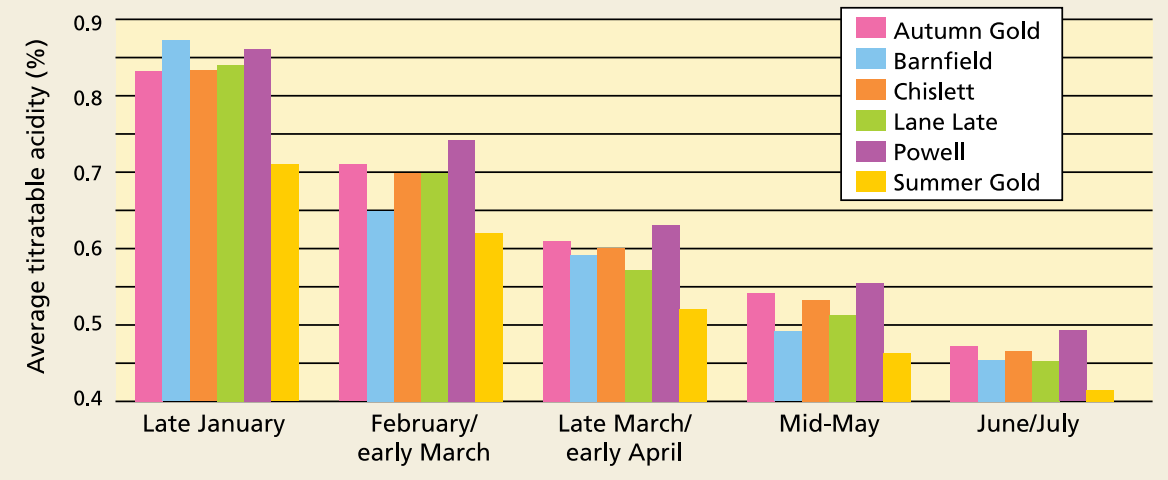

Fig. 1. Percentage titratable acidity data, pooled over 1996-2001 and multiple locations for five sample dates.

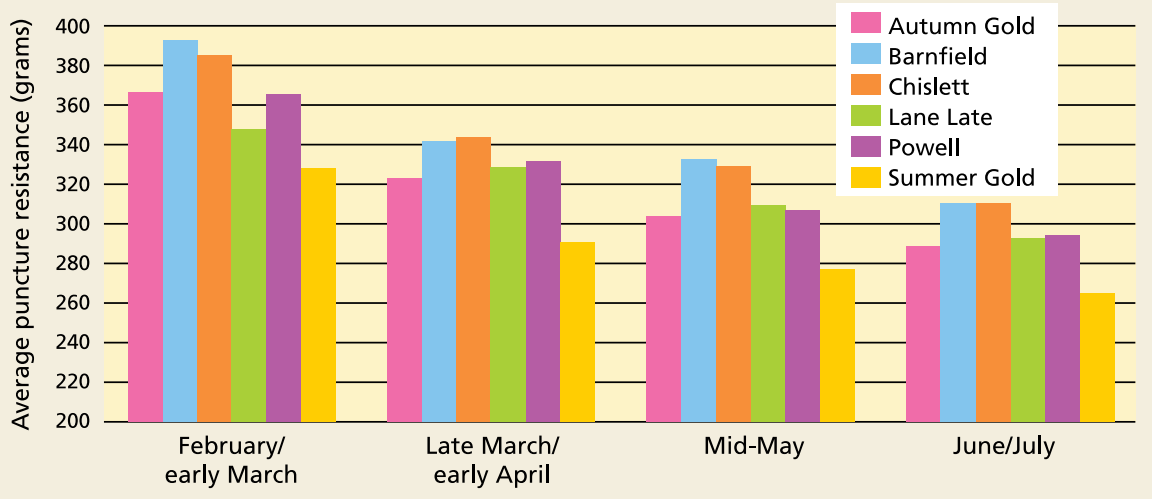

Fig. 2. Puncture-resistance data, pooled over 1997-2001 and multiple locations for four sample dates.

sample dates were added. The inclusion of nine sites, multiple sampling periods per year, and statistical analysis of the data from the seven sites that had the same five varieties, allowed comparison of both differences among selections overall and differences among selections at a particular locale.

We sampled 10 representative fruits from each tree at random positions in the tree canopy from all locations over a 2-day period, then transported the fruit to our lab, where samples were analyzed. We measured the length, width, weight and rind thickness of each sample. Puncture resistance, a test of rind firmness, was measured in grams on a custom-fabricated penetrometer, or puncture meter, which consists of a Chatillion spring push gauge, a maximum force indicator and a 0.040-inch-diameter cylindrical tip (Coggins and Lewis 1965). The cut surface of each fruit was visually evaluated for the percentage that was granulated. (Granulation is an internal physiological disorder of sweet oranges, grapefruit and some mandarins, characterized by enlarged, hardened and nearly colorless juice vesicles [Erickson 1968].)
Rind color and texture and internal color of the fruit were evaluated by correlation to standard color and texture charts. Seeds from the fruit of each sample were counted and the fruit was juiced with a Sunkist extractor. The juice from each 10-fruit sample was weighed and the percentage of juice calculated. The extracted juice was also analyzed to determine the percentage of soluble solids, mostly sugars, using an Atago PR-100 digital refractometer. The percentage of acid was determined based on citric acid by titration of a juice aliquot to $\mathrm{pH} 8.3$, with the aid of a $\mathrm{pH}$ meter. These percentages were also used to calculate the soluble solidsto-acid ratio. In California, the ratio of percentage soluble solids to percentage acid is one of the standards used to determine the legal maturity of oranges; a ratio of 8 to 1 or greater is considered mature (Barclays 2002).

\section{Maturity-related characteristics}

Maturity. Although we measured several diverse traits, it was not surprising that the consistently differing characteristics among these late navel orange varieties were related to maturity, since the bud sports were selected because they produced late-maturing fruit. When the data was averaged over all locations, some general trends were evident, but they did not take into account differences in the characteristics among locations or sample dates. Based on soluble solids-to-acid ratio data, Autumn Gold, Barnfield, Chislett and Lane Late fruit reached legal maturity around mid-January, up to 4 weeks later than Washington navel; Powell matured slightly later. On the other hand, Summer Gold fruit reached legal maturity in late December to early January, approximately the same time as Washington.

Soluble solids and acid. The soluble solids-to-acid ratio is used as a legal standard for oranges because both soluble solids and titratable acidity are closely associated with the quality of the fruit. As the fruit grows, the soluble solids concentration gradually increases and acidity decreases. In California, the acidity of mature oranges usually ranges between $1.0 \%$ and $1.3 \%$ (Sinclair 1961). When the acid level drops much lower, fruit tastes sweet but bland.

For all of the varieties evaluated, the percentage titratable acidity became progressively lower from the late January sampling date in 1996 and those from February/March through June/July from 1997 to 2001 (fig. 1). When the data was pooled over all locations and years, the percentage of titratable acids after the late January sample date was similar among Autumn Gold, Barnfield, Chislett and Lane Late fruit, but slightly higher in Powell (fig. 1); Summer Gold was considerably lower at each of the sample dates from late January to June/July. At the June/July sample date, when the data for all locations was pooled, all of the varieties had acid percentages between 0.4 and 0.5 . The lower acid percentage of Summer Gold fruit at each sample date resulted in an overall higher soluble solids-toacid ratio for this selection relative to the others (data not shown). Summer Gold's lower acid level is further indication that it matures earlier than the other selections.

Rind-softening. When the rind of navel oranges changes from green to or- 
ange, it begins to soften and continues to soften as the fruit matures and during postharvest storage (El-Otmani et al. 2000). Legal maturity actually occurs after rind-softening begins, but the rind continues to slowly soften as long as fruit hangs on the tree. Rind that is very soft is an indicator of overmature fruit. Softening rind is more susceptible to disorders such as rind staining, water spot and decreased resistance to decay from Penicillium and Geotrichum, which reduce preharvest fruit life, postharvest storage time and market value (ElOtmani et al. 2000).

At the second fruit sample date between 1997 and 2001 (late February/ early March), fruits had firm rinds that were resistant to puncture and had higher values (350 to 400 grams) for puncture resistance. Puncture resistance values decreased ( $<300$ grams) as the rind softened throughout the season (fig. 2). When the puncture resistance data for fruit of all the varieties was averaged over all locations for all sample dates, all of the varieties except Summer Gold had fruit of similar firmness.

When the puncture resistance data was averaged over all locations and years for the last three sample dates, Autumn Gold, Lane Late and Powell fruit had intermediate rind firmness and Chislett and Barnfield fruit had slightly firmer rinds. Summer Gold had considerably softer rinds than all other varieties for all sample dates (fig. 2).

Granulation. Although it is not a measure of fruit maturity, granulation occurs most often in fruit picked late in the season. It usually starts near the stem end and extends into the region closest to the core. The walls of the juice sacs thicken and stiffen, finally producing a dry, woody condition in the affected part of the fruit. Rapidly growing fruit and larger fruit have a greater tendency to granulation. Granulation varies from year to year. There was no evidence of granulation during 1999 and 2000; during 1996 and 2001, small percentages of fruit were granulated; and in May 1997 and 1998, much higher percentages of fruit were granulated. The highest levels of granulation occurred in May 1997. Because the granulation data was limited, the condition was not analyzed statistically.
In May 1997, 41\% percent of Lane Late, $26 \%$ of Powell, $16 \%$ of Summer Gold and $15 \%$ of Autumn Gold fruit exhibited granulation; no Barnfield fruit were available for evaluation. In May 1998, both Lane Late and Barnfield had the highest levels of granulation (28\%); Powell fruit had slightly less (22\%); and Chislett (18\%), Summer Gold (10\%) and Autumn Gold (4\%) had considerably less granulation. However, Barnfield fruit was evaluated at two locations whereas the others were evaluated from seven locations.

\section{Other fruit characteristics}

Although these navel varieties were chosen for lateness in maturity, they differed slightly in other fruit characteristics not related to maturity. When data for each variety was pooled over locations and years, characteristics related to fruit size, such as weight, width and length, differed among the varieties. Barnfield had the largest average weight, length and width of all the varieties evaluated for the three sample dates from February/early March through mid-May. For example, our calculation of the average number of fruit per packed carton, based on average fruit width for pooled data from the May 1998 sample date, indicated that Barnfield fruit were designated as " $48 \mathrm{~s}$," whereas all other varieties were "56s." Barnfield fruit had weights similar to

\begin{tabular}{|c|c|c|c|c|c|c|}
\hline \multirow[b]{2}{*}{ Source } & \multicolumn{3}{|c|}{ May 2000} & \multicolumn{3}{|c|}{ May 2001} \\
\hline & DF & MS & $P$ & DF & MS & $P$ \\
\hline Location (L) & 6 & 185.7470 & 0.000 & 6 & 355.3870 & 0.000 \\
\hline Variety (V) & 4 & 60.1570 & 0.000 & 4 & 144.1710 & 0.000 \\
\hline $\mathbf{L} \times \mathbf{V}$ & 24 & 12.2110 & 0.000 & 24 & 22.0280 & 0.006 \\
\hline Error & 35 & 3.0450 & & 35 & 8.7020 & \\
\hline Total & 69 & & & 69 & & \\
\hline
\end{tabular}

\begin{tabular}{|c|c|c|c|c|c|c|c|c|c|c|}
\hline \multirow[b]{2}{*}{ Location } & \multicolumn{5}{|c|}{ May 2000} & \multicolumn{5}{|c|}{ May 2001} \\
\hline & $\begin{array}{c}\text { Autumn } \\
\text { Gold }\end{array}$ & Chislett & $\begin{array}{l}\text { Lane } \\
\text { Late }\end{array}$ & Powell & $\begin{array}{c}\text { Summer } \\
\text { Gold }\end{array}$ & $\begin{array}{c}\text { Autumn } \\
\text { Gold }\end{array}$ & Chislett & $\begin{array}{l}\text { Lane } \\
\text { Late }\end{array}$ & Powell & $\begin{array}{c}\text { Summer } \\
\text { Gold }\end{array}$ \\
\hline Madera & 18.99a* & $19.71 a$ & $19.61 a$ & $18.37 a$ & $21.56 a$ & $28.15 a$ & $29.19 a$ & $23.22 \mathrm{a}$ & $21.69 a$ & $27.37 a$ \\
\hline $\begin{array}{l}\text { Orange } \\
\text { Cove }\end{array}$ & $21.50 \mathrm{~b}$ & $22.26 b$ & $23.08 \mathrm{ab}$ & $21.39 b$ & $27.99 a$ & $24.58 b c$ & $21.77 b c$ & $30.16 \mathrm{ab}$ & $20.96 c$ & $36.52 a$ \\
\hline Woodlake & $22.98 a$ & $22.89 a$ & $18.98 \mathrm{a}$ & $20.03 a$ & $23.69 a$ & $25.46 b$ & $30.59 \mathrm{ab}$ & $28.35 a b$ & $28.24 a b$ & $36.71 a$ \\
\hline Ducor & $22.02 \mathrm{ab}$ & $21.90 \mathrm{ab}$ & $17.82 \mathrm{~b}$ & $19.37 b$ & $25.53 a$ & $28.38 b$ & $27.36 \mathrm{~b}$ & $24.29 b$ & $23.01 b$ & $38.69 a$ \\
\hline Arvin & $26.40 c$ & $28.89 b c$ & $33.18 b$ & $25.18 c$ & $39.39 a$ & $30.07 b$ & $32.01 b$ & $32.63 b$ & $28.84 b$ & $41.69 a$ \\
\hline Ojai & $14.29 \mathrm{~b}$ & 17.38ab & $20.98 a$ & $15.92 b$ & 17.27ab & $17.51 \mathrm{a}$ & $18.13 a$ & $10.81 a$ & $16.83 a$ & $19.28 a$ \\
\hline Fillmore & $19.97 a b$ & $15.91 b$ & $21.16 a$ & $18.54 \mathrm{ab}$ & $21.59 a$ & $19.68 a$ & $17.53 a$ & $19.15 a$ & $18.109 a$ & $18.25 a$ \\
\hline
\end{tabular}

Chislett and Powell for the June/July sample dates.

In addition, Chislett and Powell fruit were slightly heavier on average than Lane Late, Autumn Gold and Summer Gold for all of the sample dates. Barnfield fruit also had slightly thicker rinds than the other varieties, but rind thickness is related to fruit size because larger fruit tend to have thicker rinds. However, Barnfield fruit were sampled from fewer locations than the other varieties, which may account for some of the difference.

Data pooled over locations and years for the ratio of fruit length-to-width confirmed our observations that Summer Gold fruit were slightly rounder than the other varieties. Other external traits such as rind color and texture were similar among the varieties for all sample dates. The juice percentages (a measure of fruit juiciness: juice weight divided by fruit weight) were also similar among the varieties for all sample dates, but all varieties had slightly lower juice percentages after the late January sample date. The percentages remained at or slightly below 50\% through the June/ July sample date. 


\section{Differences among locations}

Data for 15 of the fruit-quality characteristics collected from February 1998 to May 2001 for all varieties (except Barnfield) was analyzed using twoway analysis of variance (ANOVA) to investigate differences among locations (tables 2A and 3A). Because fewer experimental sites were available early in the study, and because Barnfield fruit were available at only two of the sites, not all of the data could be analyzed for statistical differences. When the interaction of locations by varieties was significant, the data was analyzed by Tukey's procedure to separate significant differences among varieties within locations (tables 2B and 3B).

For all of the sample dates except those in 1999, significant statistical differences existed among locations for all traits. Only two coastal locations with fruit were available in 1999 due to a major freeze in December 1998 that affected fruit in the San Joaquin Valley. The significant statistical differences among the locations were not surprising because the trees were exposed to different climatic conditions, altitude, rootstocks, and interstocks (tables 2A and 3A).

\begin{tabular}{|c|c|c|c|c|c|c|}
\hline \multirow[b]{2}{*}{ Source } & \multicolumn{3}{|c|}{ February 2000} & \multicolumn{3}{|c|}{ May 2000} \\
\hline & DF & MS & $P$ & DF & MS & $P$ \\
\hline Location (L) & 6 & 0.0887 & 0.000 & 6 & 0.0770 & 0.000 \\
\hline Variety (V) & 4 & 0.0270 & 0.000 & 4 & 0.0184 & 0.001 \\
\hline $\mathbf{L} \times \mathbf{V}$ & 24 & 0.0079 & 0.036 & 24 & 0.0086 & 0.004 \\
\hline Error & 38 & 0.0042 & & 35 & 0.0032 & \\
\hline Total & 72 & & & 69 & & \\
\hline
\end{tabular}

TABLE 3B. Tukey's pairwise comparisons of means among varieties within locations for percentage of juice

\begin{tabular}{|c|c|c|c|c|c|c|c|c|c|c|}
\hline \multirow[b]{2}{*}{ Location } & \multicolumn{5}{|c|}{ February 2000} & \multicolumn{5}{|c|}{ May 2000} \\
\hline & $\begin{array}{l}\text { Autumn } \\
\text { Gold }\end{array}$ & Chislett & $\begin{array}{l}\text { Lane } \\
\text { Late }\end{array}$ & Powell & $\begin{array}{c}\text { Summer } \\
\text { Gold }\end{array}$ & $\begin{array}{c}\text { Autumn } \\
\text { Gold }\end{array}$ & Chislett & $\begin{array}{l}\text { Lane } \\
\text { Late }\end{array}$ & Powell & $\begin{array}{c}\text { Summer } \\
\text { Gold }\end{array}$ \\
\hline Madera & $0.80 a *$ & $0.77 a$ & $0.82 a$ & $0.77 a$ & $0.76 a$ & $0.63 a$ & $0.60 a$ & $0.62 a$ & $0.64 a$ & $0.56 a$ \\
\hline $\begin{array}{l}\text { Orange } \\
\text { Cove }\end{array}$ & $0.74 a$ & $0.65 a$ & $0.57 a$ & $0.70 a$ & $0.58 a$ & $0.60 a$ & $0.56 a$ & $0.53 a$ & $0.57 a$ & $0.50 a$ \\
\hline Woodlake & $0.81 a$ & $0.78 a$ & $0.70 a$ & $0.70 a$ & $0.77 a$ & $0.53 b$ & $0.56 \mathrm{ab}$ & $0.71 a$ & $0.60 \mathrm{ab}$ & $0.60 \mathrm{ab}$ \\
\hline Ducor & $0.75 a$ & $0.77 a$ & $0.77 a$ & $0.82 a$ & $0.68 a$ & $0.60 a$ & $0.56 a$ & $0.62 a$ & $0.66 a$ & $0.50 a$ \\
\hline Arvin & $0.68 \mathrm{ab}$ & $0.76 a$ & $0.76 a$ & $0.75 a$ & $0.54 b$ & $0.53 a$ & $0.50 a$ & $0.41 a$ & $0.49 a$ & $0.37 a$ \\
\hline Ojai & $0.92 \mathrm{ab}$ & $0.92 \mathrm{ab}$ & $0.93 a b$ & $1.03 a$ & $0.81 b$ & $0.74 a$ & $0.68 a$ & $0.79 a$ & $0.77 a$ & $0.71 \mathrm{a}$ \\
\hline Filmore & $0.74 c$ & $0.99 a$ & $0.89 a b c$ & $0.94 \mathrm{ab}$ & $0.79 c$ & $0.66 b c$ & $0.87 a$ & $0.56 c$ & $0.72 a$ & $0.56 c$ \\
\hline
\end{tabular}

to-acid ratios than the other varieties. However, depending on the location, Summer Gold did not always have significantly higher solids-to-acid ratio than other varieties (table $2 \mathrm{~B}$ ).

In May 2000, Summer Gold fruit from Fillmore had a significantly higher solids-to-acid ratio than Chislett, but there were no significant differences among the other varieties. However, on the same date, Summer Gold fruit from Orange Cove had a significantly higher solids-to-acid ratio than Chislett, Autumn Gold and Powell but not than Lane Late, and there were no significant differences among Chislett, Autumn Gold and Powell (tables 2A and 2B). For each of the locations except Arvin and Orange Cove, there was at least one sample date when no statistically significant differences occurred among the varieties in timing of maturity based on solids-to-acid ratio (table 2).

When the location data for percentage acidity was pooled, the general trend from one year to next was that the acid levels in fruit were similar among Autumn Gold, Chislett and Lane Late, but slightly higher in Powell and considerably lower in Summer Gold. This was not always the case when data for individual locations was analyzed. At most locations and for most sample dates, Summer Gold had the lowest or one of the lowest acidity percentages, and for some locations and sample dates, Powell had the highest acidity (tables 3A and 3B).

Fruit grown at different sample dates, years and locations varied in whether there were significant differences among the varieties for percentage of acidity. For fruit sampled from Ojai in February 2000, Summer Gold had significantly lower percentage acidity than Powell but not than the other varieties. Yet fruit sampled from the same location in May 2000 had no significant differences (table 3B). In contrast, there were no significant differences in percentage acidity between fruit sampled from the two northernmost locations, Madera and Orange Cove, for the February 2000 and May 2000 sample dates (table 3). For all locations, there was at least one sample date when there was no significant difference for percentage acidity in the fruit (tables $3 \mathrm{~A}$ and $3 \mathrm{~B})$. 
Puncture resistance, a measure of rind firmness, showed similar trends, with significant interactions of location by variety. The relationship among varieties differed depending upon where they were sampled, and also collection date. For most sample dates and locations, Summer Gold fruit had the lowest average puncture-resistance values, and in some cases this was significantly different from one or more varieties. For other sample dates and locations, there were no significant differences among any of the varieties.

\section{General trends in late navels}

Overall, some general trends were apparent. Autumn Gold, Barnfield, Chislett, Powell and Lane Late had late-maturing characteristics that would extend the navel orange season. When the data was pooled over locations and years, Chislett and Barnfield had slightly firmer rinds than Autumn Gold, Powell and Lane Late, but based on pooled solids-to-acid ratio data, and percentage of titratable acidity (a component of the solids-to-acid ratio), Powell fruit matured slightly later and had slightly higher acidity. Yet no variety stood out as having the latestmaturing fruit for all traits associated with maturity for all locations. For certain locations, sample dates and years, there were significant differences among the varieties for traits associated with maturity, but these differences varied by location. In general, Summer Gold fruit matured earlier. However, for certain locations, sample dates and years, no significant differences existed for late-maturing characteristics.

One of the questions we set out to address was whether these new varieties have any advantages over Lane Late, the first commercial lateseason navel orange variety grown in California. Even though Lane Late had late-maturity characteristics, during those seasons when granulation occurred, the new varieties (including Summer Gold), generally had a lower percentage of granulated fruit than Lane Late. The prevalence of granulation can have a dramatic effect on the amount of marketable fruit, so these new varieties warrant consideration for future plantings. Another trend,

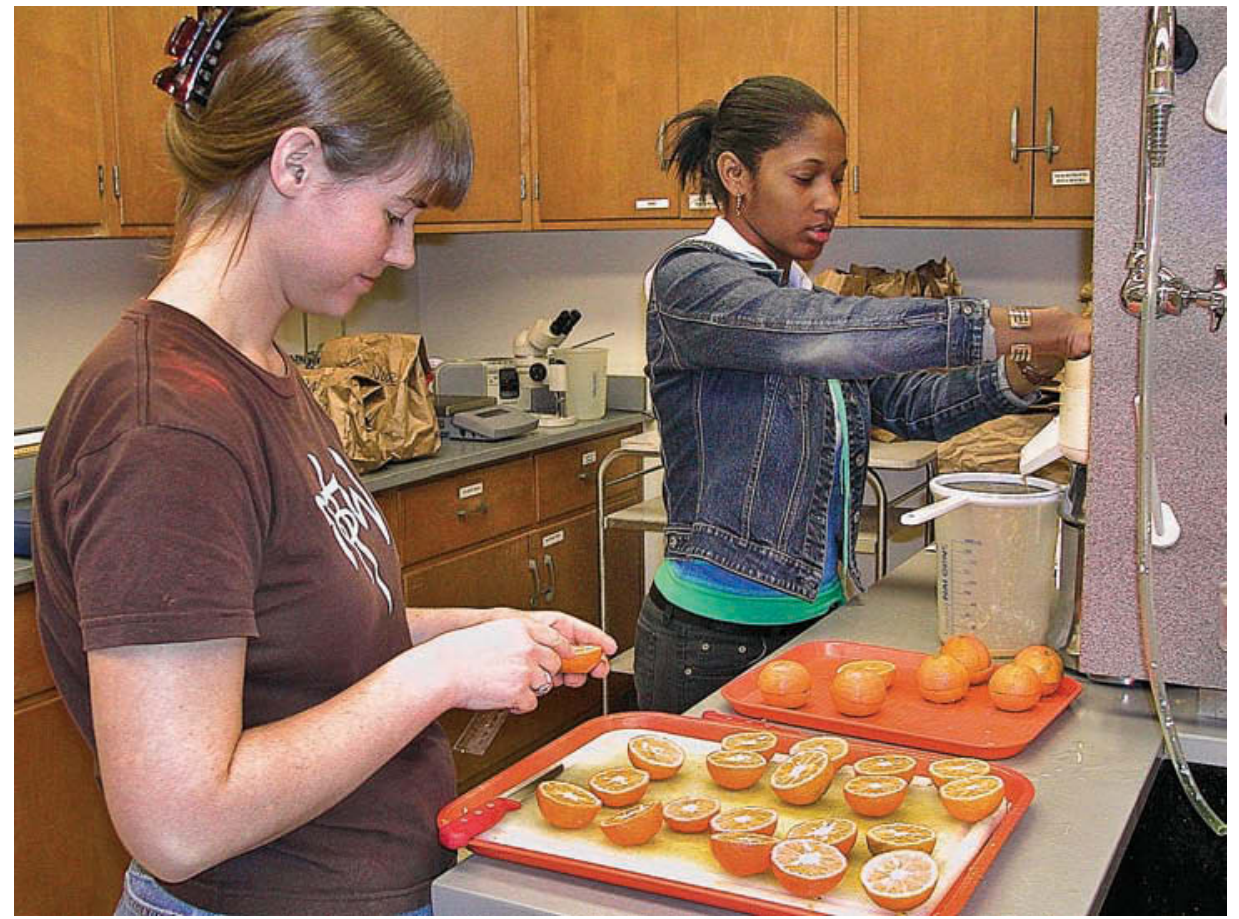

Lab assistants Juliana Lee (left) and Aundria Cherise Davis analyze orange samples at the UC Riverside laboratory.

although unrelated to lateness in maturity, was fruit size. Fruit size can be "very large" if fruit is held late. This can be an advantage for locations where small fruit size is a frequent problem. Barnfield, evaluated at only two locations, had particularly large fruit.

Given the differences in fruit characteristics at different locations for various sample dates and years, growers should consider planting more than one of the varieties with late-maturing characteristics to determine which best suits their growing conditions.

T.L. Kahn is Principal Museum Scientist and Curator of the Citrus Variety Collection; O.J. Bier is Staff Research Associate (retired), Citrus Variety Collection and Department of Botany and Plant Sciences; and R.J. Beaver is Professor of Statistics Emeritus, all at UC Riverside. We thank Star Lee, Vi Lieu, Anh Nguyen, Khanh Nguyen, Thu Ta and Kimberly Tan for their assistance with data collection from 1996 to 2001; the students in Statistics 293 C at UC Riverside during spring quarter 2002 for their assistance with statistical analysis of the data; the eight cooperators for providing fruit; and the California citrus industry groups, California Citrus Nursery Society and Citrus Research Board for their support of this project.

\section{References}

[Barclays] Barclays California Code of Regulations. 2002. California Regulatory Code Supplement Register. No 49, Title 3 1430.84.

Castle WS. 1995. Rootstock as a fruit quality factor in citrus and deciduous tree crops. New Zealand J Crop Horti Sci 23:383-94.

Coggins CW, Lewis LN. 1965. Some physical properties of the navel orange rind as related to ripening and to gibberellic acid treatments. Am Soc Hort Sci 86:272-9.

El-Otmani M, Coggins CW Jr, Agusti M, Lovatt C. 2000. Plant growth regulators in citriculture: World current uses. Crit Revs Plant Sci 19(5):395-447.

Erickson LC. 1968. The general physiology of citrus. In: The Citrus Industry, Volume II. Berkeley, CA: UC Pr. p 117-9.

Gallasch PT. 1996. Evaluating new selections of late hanging navel orange. Proc Int Soc Citriculture 1:193-7.

Gallasch PT. 1999. Evaluation report: New navel orange varieties and selections. Aust Citrus News 75:4-6.

[NASS] National Agricultural Statistics Service. 2006. California Field Office. 2005 California Citrus Acreage Report: www.nass. usda.gov/Statistics_by_State/California/Publications/Citrus/200607citac.pdf.

Nauer EM, Carson TL, Gonzales RG. 1990

The Lane Late: An appraisal. Citrograph 75 (5):100-4.

Sinclair WB. 1961. Principal juice constituents. In: The Orange, Its Biochemistry and Physiology. Berkeley, CA: UC Pr. p 131-60. 